\title{
Colorectal Carcinoma: Why Is There a Lower Incidence in Nigerians When Compared to Caucasians?
}

\author{
David Omoareghan Irabor \\ Surgery Department, College of Medicine, University of Ibadan, Ibadan, PMB 5116, Oyo State, Nigeria \\ Correspondence should be addressed to David Omoareghan Irabor, dirabor@comui.edu.ng \\ Received 7 September 2011; Revised 31 October 2011; Accepted 14 November 2011 \\ Academic Editor: L. R. Ferguson
}

Copyright (๑) 2011 David Omoareghan Irabor. This is an open access article distributed under the Creative Commons Attribution License, which permits unrestricted use, distribution, and reproduction in any medium, provided the original work is properly cited.

\begin{abstract}
Carcinoma of the colon and rectum is the 2nd commonest cancer in the United States; the leading cancer being lung cancer. It has been estimated that 130,200 new cases of colorectal cancer will be diagnosed annually while 56,300 sufferers will die from the disease (Murphy et al., 2000). In developing countries especially West Africa, the rate has not yet reached such magnitude. This suggests that there may be factors either anthropomorphic or environmental which may be responsible for this. The paper acknowledges the reduced incidence of colorectal cancer in native West Africans living in Africa and endeavours to highlight the various factors that produce this observation in medical literature. A diligent search through available literature on the aetiology, epidemiology and comparative anthropology of colorectal cancer was done. Internet search using Pubmed, British library online and Google scholar was also utilized. The rarity of adenomatous polyposis syndromes in the native West African contributes to the reduced incidence of colorectal cancer. Cancer prevention and cancer-protective factors are deemed to lie in the starchy, high-fiber, spicy, peppery foodstuff low in animal protein which many West African nations consume.
\end{abstract}

\section{Introduction}

For over 40 years, colorectal cancer incidence has reportedly been lower in West Africans than in Caucasians [2-6]. The prevalence of colorectal cancer in Caucasian countries has been linked to hereditary/genetic predispositions and environmental influences like life-style patterns and diet.

The adenoma-carcinoma sequence has been suggested to be the final pathway of these links mentioned above. In West Africa, the rarity of these colonic adenomata has led to the consideration of a different mechanism by which colorectal carcinoma develops [6-8]. This paper intends to review literature that may have relevance to the possible reason for the low incidence of colorectal carcinoma in the native West African.

\section{Discussion}

Colorectal carcinoma in Nigeria, the most populous nation in West Africa with 155 million inhabitants [9], seems to be increasing in incidence. The time trends in common cancers in men from the Ibadan cancer registry in Nigeria show that, four decades ago (1960-1969), the top five cancers in men did not include colorectal cancer. But, by the last decade, carcinoma of the colon and rectum moved from the tenth to the fourth position [10].

However, studies that have been published from various centres in the country show that the number of patients seen per year with colorectal cancer in each centre ranges from about 6 to 25 [11-18]. Each of these centres is a teaching hospital or tertiary health facility that serves populations of about one million to 1.5 million people. In a westernized country like Australia, up to 317 new cases of either colon or rectal cancers are reportedly seen yearly [19]. Incidence rates in Nigeria are put at 3.4 cases per 100,000 compared with 35.8 cases per 100,000 each year in the state of Connecticut, USA [20]. A recent study from Ibadan, Nigeria showed the average annual incidence of colorectal cancer was 27 patients per year [21]. This shows that even if it seems that incidence rates are increasing in Nigeria, such rates are still about onetenth of what is seen in the truly developed countries. This situation seems to prevail in developing countries, especially 
in Africa, and it has been shown in South Africa that, in spite of the long-established Caucasian-like dietary habits in urbanized South African blacks living in the Witwatersrand, they still have a much lower incidence of colorectal cancer than South African whites [22]. The mean age of the South African blacks studied was 54.3 years. The crude incidence of bowel cancer in the South African blacks living in the Witwatersrand was assessed as less than one-tenth of the whites living in the same location $(3.5 / 100,000 /$ year in blacks to $41 / 100,000 /$ year for whites) despite 3 to 4 generations of "westernization" of the blacks. The authors were unable to find a reportable reason for this difference [22]. These Caucasian-like diets include grilled meats like steaks, deepfried chicken, and burger meats which are served in evergrowing and popular western fast-food establishments. In a bid to find reasons and explanations for this observed rarity of colon and rectal cancer in West Africans generally and Nigerians specifically, this review will concentrate on the following areas.

2.1. Colonic Adenomatous Polyps. Only four cases of adenomatous polyposis have been reported in Nigeria in the last 35 years $[7,23-25]$, and two cases of hereditary nonpolyposis colon cancer have been reported within the last 15 years [26]. This relative absence of premalignant conditions like adenomatous polyps in the West African has been reported by several authors $[8,12,21,27,28]$. This lack of a detectable adenoma-carcinoma sequence in Africans may indicate a different aetiopathogenesis of colorectal cancer. In addition, the relatively younger age at which Africans develop this disease has also been said to be against the adenomacarcinoma link $[13,21,29,30]$. The mean age of patients with colorectal cancer in Ibadan was 41 years in a study by Irabor et al. [21], and studies have shown that the age when colonic polyps start to develop is in the late 1940s to subsequently undergo malignant change 15-20 years after $[8,20]$. The incidence of colorectal cancer in Nigeria has been estimated to be $3.4 / 100,000 /$ year [20]. In the United Kingdom, comparing the incidence rates for the age of 50 and below, it was found that for those between 40-44 years it was $12 / 100,000 /$ year and $24 / 100,000 /$ year for ages $45-49$ [31]. This shows that, even though Nigerians have an average life span of 49 years, the incidence of CRC is still less than their Caucasian counterparts when comparable age groups are scrutinized. Nevertheless, one can only speculate whether Nigerians would eventually develop adenomatous polyps or have comparable incidence rates of CRC if the life expectancy increases to seventy or eighty years.

2.2. Diet. This is one area that has been extensively researched in the epidemiology of colorectal carcinoma. Appreciation of the environmental dependence of bowel cancer was noticed from migration studies as one can see the contrast between American blacks, who now have an incidence comparable to Caucasians, and that of native Africans. This is because these migrants have adopted the dietary customs of their new country [8]. Indeed, the idea that colon cancer is linked to diet is usually credited to Dennis
Burkitt who reported that colorectal cancer was rare among rural Africans. This, he suggested, was because Africans had little meat in their diet and instead ate a lot of fibre from fruits, grains, and vegetables [8]. Colonic adenocarcinoma is the 3rd commonest malignant neoplasm in societies with western type lifestyle as diet rich in red meat and fat, lacking in vegetables, fruit, and fibre is implicated in colonic carcinogenesis $[3,4,8]$. It is without doubt that countries that consume a lot of meat and animal fat have the highest rates of colon cancer, and this inversely correlates with the consumption of dietary fiber [32-34]. The protection that fibre offers has been shown to be dependent on the type of fibre consumed as many studies have found no protective effect of cereals type fibre and have consistently found a protective effect of vegetable and fruit fiber [34-38]. The typical West African diet consists of a carbohydrate-based bolus type of meal which cannot be consumed alone but with soup that is usually vegetable based. In very rural and poor communities, meat is hardly eaten and fleshy fruits may be the lunch or dinner of many. Another problem concerning meat intake is the mode of preparation or cooking of the meat. Meat cooked at high temperatures contains a class of carcinogens called heterocyclic amines (HCAs) [38-40]. These are produced when meat is heated above $180^{\circ} \mathrm{C}$ for long periods, and these HCAs have consistently been identified in well-done meat products from the North American diet $[40,41]$. The poor electricity supply in most rural and urban areas in this country (Nigeria) does not allow proper refrigeration of meat, thus many households deepfry meat for preservation and consumption. Meat grilled or barbecued contains the highest amount of polycyclic aromatic hydrocarbons (PAHs) because of the exposure to smoke formed from the pyrolysis of fatty juices that drip down onto the heat source [40]. Maybe this may have a role to play in some of the colon cancers seen in these parts. Indeed, some authors have alluded to the carcinogenic properties of charcoal-roasted meat called "suya" in Nigeria $[42,43]$. However, meat intake forms a small part of the Nigerian diet, consequently exposure to PAHs and HCAs is likely to be minimal and not in the magnitude at which Caucasians are exposed to these carcinogens.

The carbohydrate-based diet of Nigerians had been mentioned earlier, and this has been shown to be protective against the development of colon cancer. The human colonic bacteria ferment starch and nonstarch polysaccharides to short-chain fatty acids, mainly acetate, proprionate, and butyrate [44]. Butyrate has been found to be a preferred substrate for colonocytes and appears to promote a normal phenotype in these cells $[44,45]$. Resistant starch fermentation favours butyrate production and may be more protective against colorectal cancer than nonstarch polysaccharides which are the major components of dietary fiber [44-48]. Also the resistant starch from maize has been shown experimentally to produce more "colon-friendly" butyrate than that of potato starch [45]. Cassava may also, by a different mechanism, be protective against cancer because it contains a chemical called tamarin which is responsible for the production of hydrocyanide. This tamarin has been shown in vitro to cause death of cancer cells by self-toxicity with 
hydrocyanide [49]. The Nigerian diet favours a variety of maize- and cassava-based bolus meals.

2.3. Spices and Phytonutrients. Epidemiological data supports the fact that the lowest incidence rates of colorectal cancer are found in India, Asia, and Africa [50-53]. These are also the places where foods are hot and spicy. The typical Nigerian stews are hot and spicy with a base of ground tomatoes, red chilli peppers, and onions (in various proportions depending on the individual or community preference) which are then cooked in palm oil or vegetable oil till everything blends. This has led to a closer look at these phytonutrients as they are now called and their mode of protection against colorectal cancer. Turmeric (curcumin), which is an ingredient in Indian curry, has anticancer properties [5457]. Curcumin is diferuloylmethane, and it targets multiple signalling pathways that may protect the colon by decreasing the activity of beta-glucuronidase and mucinase [54, 55]. Other anticancer properties of curcumin include inhibition of lipooxygenase activity, specific inhibition of cyclooxygenase 2 expression, and the promotion/progression stages of carcinogenesis $[55,56]$.

Garlic and onions, which contain diallyl sulphide, were found to suppress cell division in human colon tumor cells [57]. Onions have an additional anticancer property as a result of their high antioxidant property (due to their wide content of flavonoids) [58], and they are much more widely used in Nigeria than garlic; indeed, raw onions are commonly eaten with charcoal-roasted meat called "suya." All stews and soups cooked in Nigeria have onions as essential ingredients. Curcumin which is in Indian curry is also widely used in cooking in Nigeria but not as much as Indian cooking. Red pepper which is used widely in Nigerian cooking has been shown to protect against colorectal carcinoma $[59,60]$. The main ingredient of red chili pepper is capsaicin, and this is known to cause death of colon cancer cells [60].

2.4. Body Weight/Size and Physical Activity. Increased caloric intake and reduced physical activity seems to be the sign of improved economic development and civilization, and this leads to obesity which is a common ailment in the United States [61]. Many studies have shown a link between an increase in body size and colorectal cancer [61-65]. Those who indulge in a lot of physical activity have a lower chance of developing colorectal cancer [61,63]. In the developing countries, the level of poverty precludes the luxury of overindulgence in food and ensures continuous physical activity either from farming, manual labour, or selfemployment. For in the developing countries, one starves if one does not work. Ironically, this has now been seen to reduce the chance of developing colorectal cancer because obesity and lack of physical activity are not as common in West Africans in general and Nigerians in particular when compared to the population of the United States [63].

2.5. Malabsorption/Lactose Intolerance. Lactose intolerance is seen more in the African race than in Caucasians. Interestingly, the malabsorption that this causes has now been hypothesized to be a protective factor against the development of colorectal cancer [66]. This "protective factor" stems from the fact that malabsorption increases the concentration of fermentable substances reaching the colon and shortens the intestinal transit time [67]. The maintenance of a normal phenotype in colon cells is said to be influenced by shortchain fatty acids, especially butyrate, which are formed in the colon from fermentation of carbohydrates, especially resistant starch $[44,45]$. Supporting this is the fact that shortchain fatty acid production is significantly higher in native Africans than in Caucasians [68]. Asians and Africans, as earlier mentioned, have the lowest incidences of colorectal cancer worldwide, and reports have shown that $90 \%$ of Asians and Africans are said to lack the lactase enzyme [66]. In terms of the history of dairying in Africa, it was determined that Nigeria straddles the boundary between the traditional zones of milking and nonmilking. The Fulanis, mainly cattle rearers, who lived in the north were milk users and were found to be lactose absorbers in contrast to the Yorubas in southern Nigeria who lived in a nonmilking zone and were predominantly lactose intolerant. The prevalence of lactose intolerance has been estimated at $52 \%$ for the Fulani, $85.9 \%$ for the Yoruba and Ibo, and $76 \%$ for the Hausa in Nigeria $[69,70]$. Majority of South African blacks are lactose intolerant irrespective of tribe of origin, and this is attributed to origination and migration of South African blacks from the west and central African zone of nonmilking [70].

2.6. Sunlight and Vitamin D. West Africa is blessed with sunlight all year round. Sunlight is important in the peripheral manufacture of vitamin D in the human body. Vitamin $\mathrm{D}$ and calcium have been shown to be protective against colorectal cancer $[71,72]$. Countries that receive the highest amount of sunshine annually include those in West and North Africa, the Middle East, and Pakistan [73], and these are the places that have very low incidences of colorectal cancer $[52,53,74]$. Thus, geographical serendipity also plays a part in the provision of factors that keep the incidence of colorectal cancer low in West Africans.

To conclude, one may infer that the explanation why the incidence of colorectal cancer in West Africans as a whole and in Nigerians specifically remains low is rooted in (a) the rarity of adenomatous polyposis syndromes, (b) the protective effects of our starch-based, vegetable-based, fruit-based, and spicy, peppery diet, and (c) our geographical location which ensures sunshine all year round.

\section{References}

[1] P. Murphy, G. Petersen, S. Thibodeau, and R. Fishel, "Genetic testing for colon cancer: joint statement of the American College of Medical Genetics and American Society of Human Genetics," Genetics in Medicine, vol. 2, no. 6, pp. 362-366, 2000.

[2] J. Higginson, "Gastrointestinal cancer in Africa, South of the Sahara," Acta-Unio Internationalis Contra Cancrum, vol. 17, pp. 333-338, 1961.

[3] J. H. Weisburger, "Colon carcinogens: their metabolism and mode of action," Cancer, vol. 28, no. 1, pp. 60-70, 1971. 
[4] M. J. Hill, "Cancer of the large bowel: human carcinogenesis," British Journal of Surgery, vol. 72, pp. S37-S39, 1985.

[5] I. Segal, C. A. Edwards, and A. R. P. Walker, "Continuing low colon cancer incidence in African populations," American Journal of Gastroenterology, vol. 95, no. 4, pp. 859-860, 2000.

[6] O. O. Adekunle and J. A. Lawani, "Clinical aspects and management of carcinoma of the rectum in Nigerians," East African Medical Journal, vol. 59, no. 3, pp. 206-213, 1982.

[7] O. B. Alese and D. O. Irabor, "Adenomatous polyposis coli in an elderly female Nigerian," Ghana Medical Journal, vol. 43, pp. 139-141, 2009.

[8] D. P. Burkitt, "Epidemiology of cancer of the colon and rectum," Cancer, vol. 28, no. 1, pp. 3-13, 1971.

[9] Nigeria Demographics Profile, 2011, http://www.indexmundi. com/nigeria/demographics_profile.html.

[10] M. N. Okobia, "Cancer care in sub-Saharan Africa- urgent need for population-based cancer registries," The Ethiopian Journal of Health Development, vol. 17, pp. 89-98, 2003.

[11] O. O. Adekunle and A. A. Abioye, "Adenocarcinoma of the large bowel in Nigerians: a clinicopathologic study," Diseases of the Colon and Rectum, vol. 23, no. 8, pp. 559-563, 1980.

[12] Y. Iliyasu, J. K. Ladipo, E. E. U. Akang, C. A. Adebamowo, O. G. Ajao, and P. U. Aghadiuno, "A twenty-year review of malignant colorectal neoplasms at University College Hospital, Ibadan, Nigeria," Diseases of the Colon and Rectum, vol. 39, no. 5, pp. 536-540, 1996.

[13] O. O. Akute, "Colorectal carcinoma in Ibadan, Nigeria: a 20year survey-1971 to 1990," Hepato-Gastroenterology, vol. 47, no. 33, pp. 709-713, 2000.

[14] D. C. Nwafo and J. O. Ojukwu, "Malignant disease of the colon, rectum, and anus in Nigerian Igbos," Annals of the Royal College of Surgeons of England, vol. 62, no. 2, pp. 133-135, 1980.

[15] A. Z. Sule, B. M. Mandong, and D. Iya, "Malignant colorectal tumours: a ten year review in Jos, Nigeria," West African Journal of Medicine, vol. 20, no. 4, pp. 251-255, 2001.

[16] S. T. Edino, A. Z. Mohammed, and O. Ochicha, "Characteristics of colorectal carcinoma in Kano, Nigeria: an analysis of 50 cases," Nigerian Journal of Medicine, vol. 14, no. 2, pp. 161166, 2005.

[17] D. O. Akinola and A. O. Arigbabu, "Pattern and presentation of large bowel neoplasms in Nigerians," Central African Journal of Medicine, vol. 40, no. 4, pp. 98-102, 1994.

[18] A. A. Adesanya and J. T. da Rocha-Afodu, "Colorectal cancer in Lagos: a critical review of 100 cases," The Nigerian Postgraduate Medical Journal, vol. 7, no. 3, pp. 129-136, 2000.

[19] C. G. Luke, B. Koczwara, J. E. Moore et al., "Treatment and survival from colorectal cancer: the experience of patients at South Australian teaching hospitals between 1980 and 2002," Clinical Oncology, vol. 17, no. 5, pp. 372-381, 2005.

[20] J. Sack and J. M. Rothman, "Colorectal carcinoma: natural history and management," Hospital Physician, vol. 36, pp. 64$73,2000$.

[21] D. O. Irabor, A. Arowolo, and A. A. Afolabi, "Colon and rectal cancer in Ibadan, Nigeria: an update," Colorectal Disease, vol. 12, pp. e43-e49, 2010.

[22] I. Segal, "Rarity of colorectal adenomas in the African black population," European Journal of Cancer Prevention, vol. 7, no. 5, pp. 387-391, 1998.

[23] O. O. Adekunle and G. O. Ajao, "Colorectal cancer in adolescent Nigerians," Scandinavian Journal of Gastroenterology, Supplement, vol. 21, no. 124, pp. 183-186, 1986.
[24] S. U. Udofot, M. D. Ekpo, and M. I. Khalil, "Familial polyposis coli: an unusual case in West Africa," Central African Journal of Medicine, vol. 38, no. 1, pp. 44-48, 1992.

[25] B. J. Olasode and O. A. Olasode, "Missed diagnosis-adenomatous polyposis coli," The Central African Journal of Medicine, vol. 43, no. 11, article 339, 1997.

[26] C. A. Adebamowo, O. Adeyi, R. Pyatt, T. W. Prior, R. B. Chadwick, and A. de la Chapelle, "Case report on hereditary non-polyposis colon cancer (HNPCC) in Nigeria," African Journal of Medicine and Medical Sciences, vol. 29, no. 1, pp. 71-73, 2000.

[27] D. Irabor and O. A. Adedeji, "Colorectal cancer in Nigeria: 40 years on. A review," European Journal of Cancer Care, vol. 18, no. 2, pp. 110-115, 2009.

[28] K. Jaskiewicz, E. Lancaster, L. Banach, and A. Karmolinski, "Proliferative activity of normal and neoplastic colonic mucosa in population groups with high and low risk for colorectal carcinoma," Anticancer Research, vol. 18, no. 6, pp. 4641-4644, 1998.

[29] H. Boytchev, S. Marcovic, and G. J. Oettle, "The characteristics of large bowel cancer in the low-risk black population of the Witwatersrand," Journal of the Royal College of Surgeons of Edinburgh, vol. 44, no. 6, pp. 366-370, 1999.

[30] O. G. Ajao, M. O. Adenuga, and J. K. Ladipo, "Colorectal carcinoma in patients under the age of 30 years: a review of 11 cases," Journal of the Royal College of Surgeons of Edinburgh, vol. 33, no. 5, pp. 277-279, 1988.

[31] Bowel (Colorectal) cancer. UK-incidence statistics. Cancer Research UK, 2011.

[32] C. Barbatis, The histopathology of colorectal cancer. Archives of Hellenic Pathology, 1995, http://www.mednet.gr/hsap/ ap09301e.htm.

[33] W. C. Willett, M. J. Stampfer, G. A. Colditz, B. A. Rosner, and F. E. Speizer, "Relation of meat, fat, and fiber intake to the risk of colon cancer in a prospective study among women," The New England Journal of Medicine, vol. 323, no. 24, pp. 1664-1672, 1990.

[34] E. Kampman, M. L. Slattery, J. Bigler et al., "Meat consumption, genetic susceptibility, and colon cancer risk: a United States multicenter case-control study," Cancer Epidemiology Biomarkers and Prevention, vol. 8, no. 1, pp. 15-24, 1999.

[35] P. Boyle and J. S. Langman, "ABC of colorectal cancer epidemiology," British Medical Journal, vol. 321, no. 7264, pp. 805-808, 2000.

[36] M. Ponz de Leon, "Prevention and chemoprevention of colorectal neoplasms," Digestive and Liver Disease, vol. 34, no. 1, pp. 59-69, 2002.

[37] A. Schatzkin, E. Lanza, D. Corle et al., "Lack of effect of a lowfat, high-fiber diet on the recurrence of colorectal adenomas," The New England Journal of Medicine, vol. 342, no. 16, pp. 1149-1155, 2000.

[38] D. S. Alberts, M. E. Martínez, D. J. Roe et al., "Lack of effect of a high-fiber cereal supplement on the recurrence of colorectal adenomas," The New England Journal of Medicine, vol. 342, no. 16, pp. 1156-1162, 2000.

[39] G. N. Wogan, S. S. Hecht, J. S. Felton, A. H. Conney, and L. A. Loeb, "Environmental and chemical carcinogenesis," Seminars in Cancer Biology, vol. 14, no. 6, pp. 473-486, 2004.

[40] A. H. Wu, D. Shibata, M. C. Yu, M. Y. Lai, and R. K. Ross, "Dietary heterocyclic amines and microsatellite instability in colon adenocarcinomas," Carcinogenesis, vol. 22, no. 10, pp. 1681-1684, 2001. 
[41] L. M. Butler, R. Sinha, R. C. Millikan et al., "Heterocyclic amines, meat intake, and association with colon cancer in a population-based study," American Journal of Epidemiology, vol. 157, no. 5, pp. 434-445, 2003.

[42] G. O. Emerole, "Carcinogenic polycyclic aromatic hydrocarbons in some Nigerian foods," Bulletin of Environmental Contamination and Toxicology, vol. 24, no. 5, pp. 641-646, 1980.

[43] E. Olatunde Farombi, "Diet-related cancer and prevention using anticarcinogens," African Journal of Biotechnology, vol. 3, no. 12, pp. 651-661, 2004.

[44] D. L. Topping and P. M. Clifton, "Short-chain fatty acids and human colonic function: roles of resistant starch and nonstarch polysaccharides," Physiological Reviews, vol. 81, no. 3, pp. 1031-1064, 2001.

[45] L. J. M. Martin, H. J. W. Dumon, G. Lecannu, and M. M. J. Champ, "Potato and high-amylose maize starches are not equivalent producers of butyrate for the colonic mucosa," British Journal of Nutrition, vol. 84, no. 5, pp. 689-696, 2000.

[46] G. P. Young and R. K. Le Leu, "Resistant starch and colorectal neoplasia," Journal of AOAC International, vol. 87, no. 3, pp. 775-786, 2004.

[47] S. Toden, A. R. Bird, D. L. Topping, and M. A. Conlon, "Resistant starch prevents colonic DNA damage induced by high dietary cooked red meat or casein in rats," Cancer Biology and Therapy, vol. 5, no. 3, pp. 267-272, 2006.

[48] R. Ahmed, I. Segal, and H. Hassan, "Fermentation of dietary starch in humans," American Journal of Gastroenterology, vol. 95, no. 4, pp. 1017-1020, 2000.

[49] P. Marandola, K. Bova, M. A. Labib et al., "Cancer and nutrition in Africa in the postgenomic and proteomics era," African Journal of Urology, vol. 10, pp. 178-197, 2004.

[50] P. Boyle, D. G. Zaridze, and M. Smans, "Descriptive epidemiology of colorectal cancer," International Journal of Cancer, vol. 36, no. 1, pp. 9-18, 1985.

[51] E. Giovannucci and W. C. Willett, "Dietary factors and risk of colon cancer," Annals of Medicine, vol. 26, no. 6, pp. 443-452, 1994.

[52] M. Moshkowitz and N. Arber, "Differences in incidence and distribution of colorectal cancer among races and ethnic societies: lifestyle, genes or both?” Digestion, vol. 72, no. 4, pp. 219-222, 2005.

[53] R. Sinha, D. E. Anderson, S. S. McDonald, and P. Greenwald, "Cancer risk and diet in India," Journal of Postgraduate Medicine, vol. 49, no. 3, pp. 222-228, 2003.

[54] S. Narayan, "Curcumin, a multi-functional chemopreventive agent, blocks growth of colon cancer cells by targeting $\beta$ catenin-mediated transactivation and cell-cell adhesion pathways," Journal of Molecular Histology, vol. 35, no. 3, pp. 301307, 2004.

[55] N. Nalini, K. Sabitha, P. Viswanathan, and V. P. Menon, "Influence of spices on the bacterial (enzyme) activity in experimental colon cancer," Journal of Ethnopharmacology, vol. 62, no. 1, pp. 15-24, 1998.

[56] D. P. Chauhan, "Chemotherapeutic potential of curcumin for colorectal cancer," Current Pharmaceutical Design, vol. 8, no. 19, pp. 1695-1706, 2002.

[57] P. Greenwald, "Science, medicine, and the future: cancer chemoprevention," British Medical Journal, vol. 324, no. 7339, pp. 714-718, 2002.

[58] C. Galeone, C. Pelucchi, F. Levi et al., "Onion and garlic use and human cancer," American Journal of Clinical Nutrition, vol. 84, no. 5, pp. 1027-1032, 2006.
[59] T. Narisawa, Y. Fukaura, M. Hasebe, S. Nomura, S. Oshima, and T. Inakuma, "Prevention of N-methylnitrosourea-induced colon carcinogenesis in rats by oxygenated carotenoid capsanthin and capsanthin-rich paprika juice," Proceedings of the Society for Experimental Biology and Medicine, vol. 224, no. 2, pp. 116-122, 2000.

[60] C. S. Kim, W. H. Park, J. Y. Park et al., "Capsaicin, a spicy component of hot pepper, induces apoptosis by activation of the peroxisome proliferator-activated receptor $\gamma$ in HT-29 human colon cancer cells," Journal of Medicinal Food, vol. 7, no. 3, pp. 267-273, 2004.

[61] T. Stürmer, J. E. Buring, I. M. Lee, J. M. Gaziano, and R. J. Glynn, "Metabolic abnormalities and risk for colorectal cancer in the physicians' health study," Cancer Epidemiology Biomarkers and Prevention, vol. 15, no. 12, pp. 2391-2397, 2006.

[62] M. C. Boutron-Ruault, P. Senesse, S. Méance, C. Belghiti, and J. Faivre, "Energy intake, body mass index, physical activity, and the colorectal adenoma-carcinoma sequence," Nutrition and Cancer, vol. 39, no. 1, pp. 50-57, 2001.

[63] R. A. Durazo-Arvizu, A. Luke, R. S. Cooper et al., "Rapid increases in obesity in Jamaica, compared to Nigeria and the United States," BMC Public Health, vol. 8, article 133, 2008.

[64] T. Pischon, P. H. Lahmann, H. Boeing et al., "Body size and risk of colon and rectal cancer in the European Prospective Investigation into Cancer and Nutrition (EPIC)," Journal of the National Cancer Institute, vol. 98, no. 13, pp. 920-931, 2006.

[65] E. Giovanucci, "Obesity, insulin and colon cancer," American Association for Cancer Research, vol. 45, article 1319, 2004.

[66] I. Segal, "Physiological small bowel malabsorption of carbohydrates protects against large bowel diseases in africans," Journal of Gastroenterology and Hepatology, vol. 17, no. 3, pp. 249-252, 2002.

[67] A. Perino, S. Cabras, D. Obinu, and L. C. Sforza, "Lactose intolerance: a non-allergic disorder often managed by allergologists," European Annals of Allergy and Clinical Immunology, vol. 41, no. 1, pp. 3-16, 2009.

[68] I. Segal, H. Hassan, A. R. P. Walker, P. Becker, and J. Braganza, "Fecal short chain fatty acids in South African urban Africans and whites," Diseases of the Colon and Rectum, vol. 38, no. 7, pp. 732-734, 1995.

[69] N. Kretchmer, O. Ransome-Kuti, R. Hurwitz, C. Dungy, and W. Alakija, "Intestinal absorption of lactose in Nigerian ethnic groups,” The Lancet, vol. 2, no. 7721, pp. 392-395, 1971.

[70] I. Segal, P. P. Gagjee, A. R. Essop, and A. M. Noormohamed, "Lactase deficiency in the South African Black population," American Journal of Clinical Nutrition, vol. 38, no. 6, pp. 901905, 1983.

[71] C. F. Garland and F. C. Garland, "Do sunlight and vitamin D reduce the likelihood of colon cancer?" International Journal of Epidemiology, vol. 35, no. 2, pp. 217-220, 2006.

[72] R. P. Heaney, "Research and public health implications of the intricate relationship between calcium and vitamin D in the prevention of colorectal neoplasia," Journal of the National Cancer Institute, vol. 96, no. 10, pp. 805-807, 2004.

[73] World Sunshine Map, 2011, http://earth.rice.edu/mtpe/geo/ geosphere/hot/energyfuture/Sunlight.html.

[74] D. M. Parkin, F. Bray, J. Ferlay, and P. Pisani, "Global cancer statistics, 2002," Ca-A Cancer Journal for Clinicians, vol. 55, no. 2, pp. 74-108, 2005. 


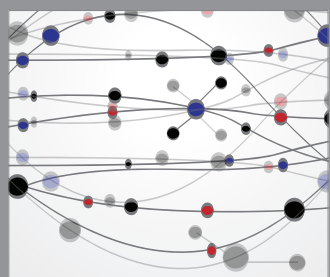

The Scientific World Journal
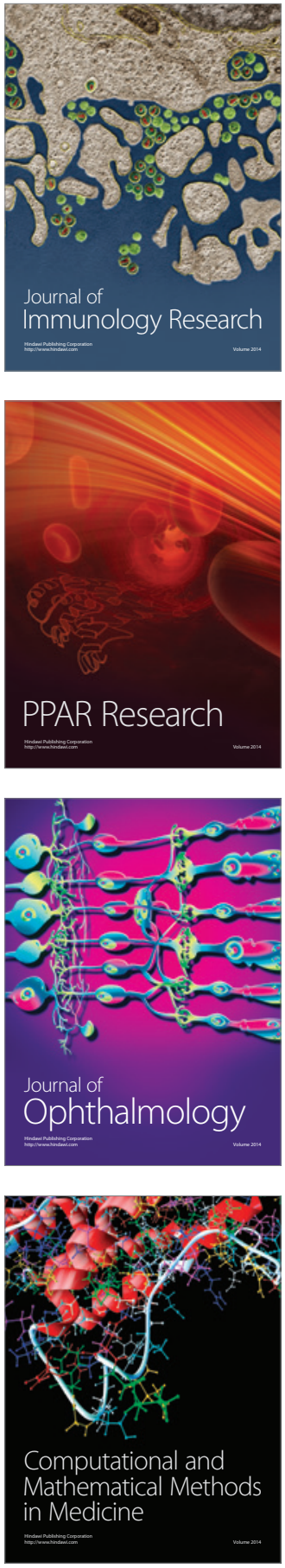

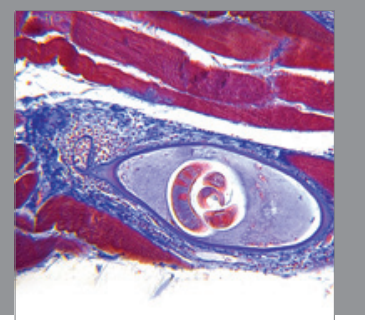

Gastroenterology

Research and Practice
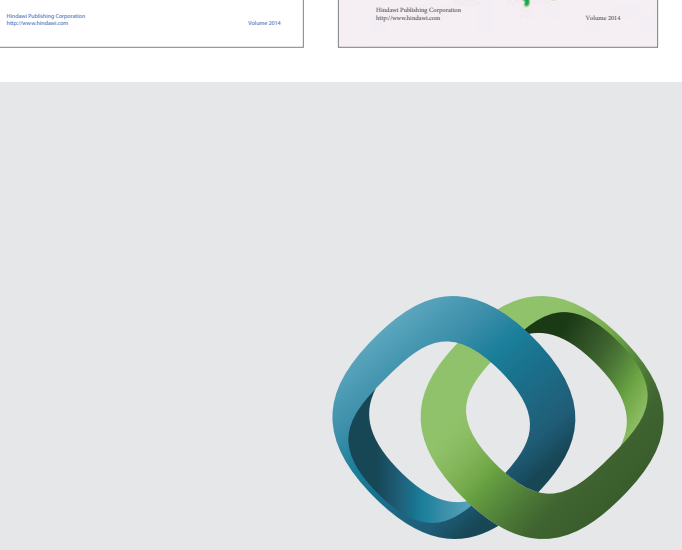

\section{Hindawi}

Submit your manuscripts at

http://www.hindawi.com
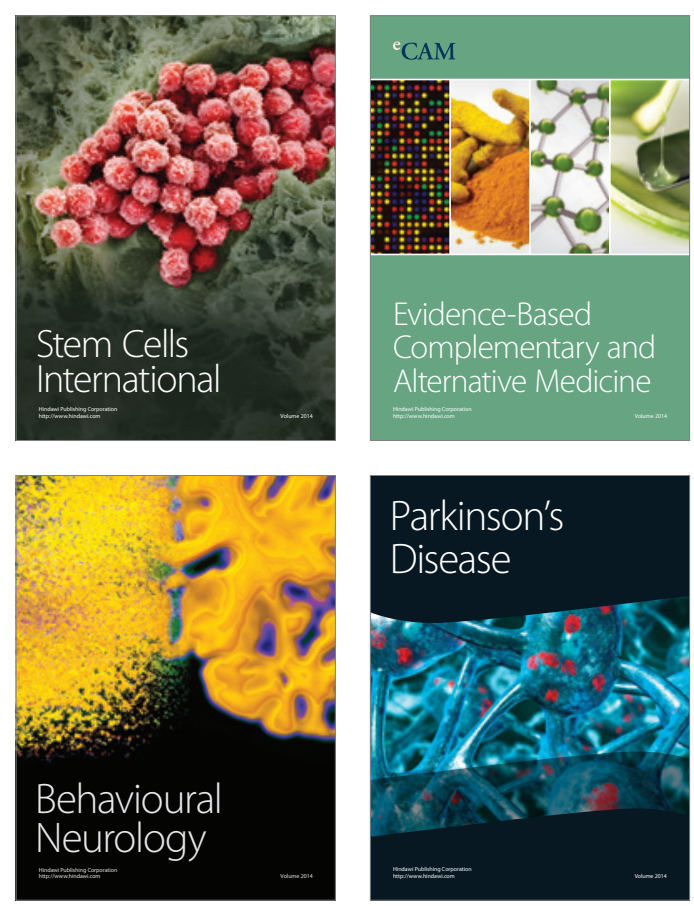

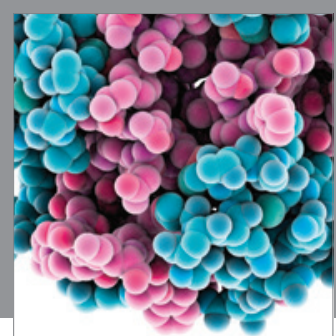

Journal of
Diabetes Research

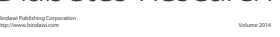

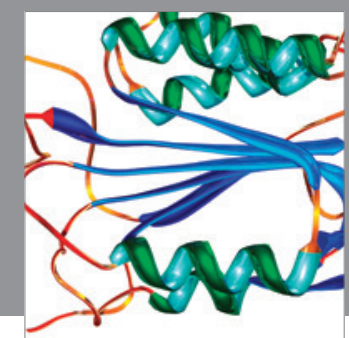

Disease Markers
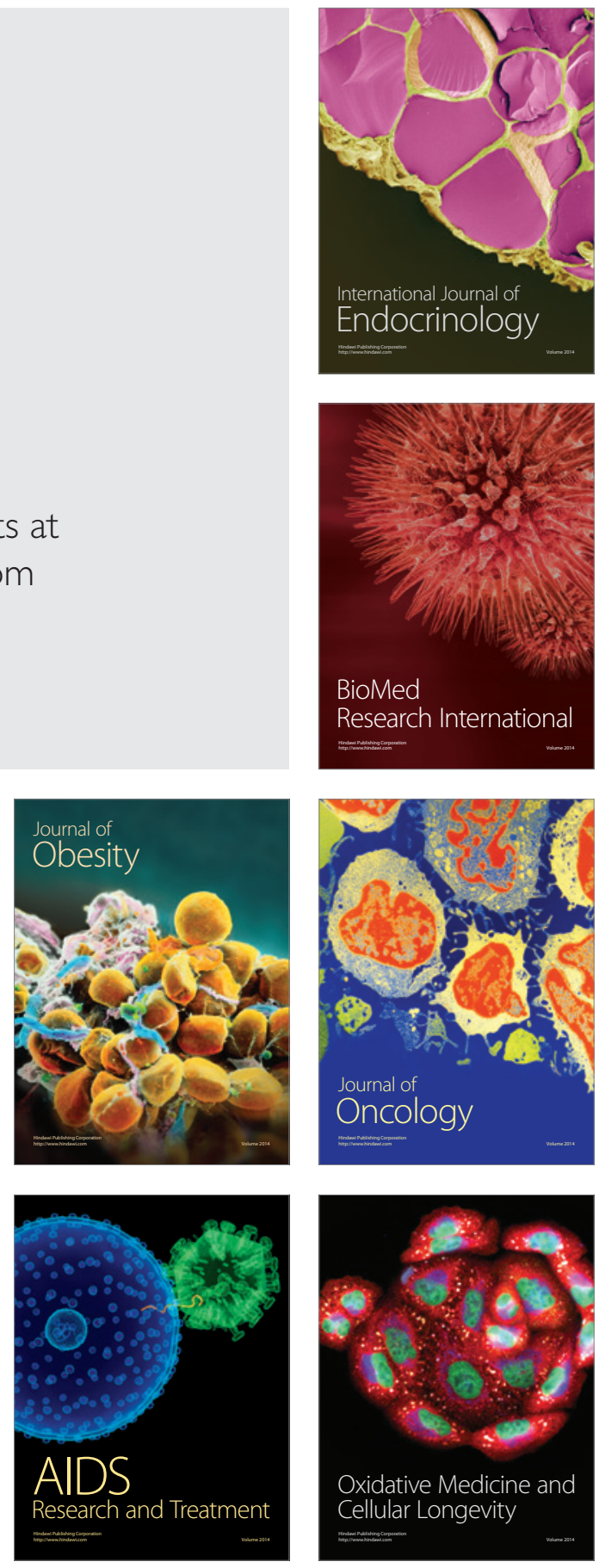